\title{
Editorial
}

\section{Reauthorization of the State Children's Health Insurance Program: Divergent Ideologies or Fiscal Realities?}

The State Child Health Insurance Program (SCHIP) provides health care access for low-income children not covered by Medicaid. Established under Title XXI of the Social Security Act (PL 105-33), SCHIP initially provided $\$ 40$ billion over 10 years to states that chose to enroll low-income children. ${ }^{1,2}$ The program is a collaborative federal-state partnership: the states are responsible for administering the program, and the federal government provides an average state funding match of $70 \% .^{3}$ States are given flexibility in terms of program design. They may use the funding either to expand Medicaid or to create new child health programs. ${ }^{4}$ The intent of the program was to expand health insurance coverage for "uninsured children living in families with income that is modest but too high to qualify for Medicaid." 2 According to statute, this means that children living in families with incomes below $200 \%$ of the federal poverty level (FPL) (\$33,200 annual income for a family of 3 in $2006^{5}$ ) or $50 \%$ of the Medicaid threshold are eligible for SCHIP. ${ }^{2}$ Covered health services include inpatient and outpatient hospital services, physician visits, prescription drugs, immunizations, dental and hearing services, and rehabilitative, therapeutic, and preventive services. ${ }^{1}$

SCHIP has increased health insurance coverage and access. The rate of uninsured children living in families between $100 \%$ and $200 \%$ of the FPL dropped from 22.5\% in 1996 (before SCHIP) to $16.9 \%$ in 2005, a 25\% decrease. $^{2}$ The number of children with health benefits increased from 660,000 in fiscal year 1998 to 6.6 million in fiscal year 2006. ${ }^{6}$ However, according to the Congressional Budget Office, "the uninsured rate among higherincome children [ie, those who did not qualify for SCHIP] remained relatively stable" 2 between 1996 and 2005. Insurance coverage influences access to and utilization of health services, both of which are critical factors in the prevention and management of childhood diseases. In 1997-1998, the mean percentage of children aged $\leq 18$ years who did not have a clinic or doctor's office visit within the previous 12 months was $10.1 \%$ for those covered under Medicaid and $28.8 \%$ for the uninsured; the corresponding rates were $10.3 \%$ and $31.9 \%$ in 2001-2002, and $9.7 \%$ and $30.9 \%$ in $2004-2005.7$ Moreover, approximately $90 \%$ of children enrolled through SCHIP report having a usual source of medical care, ${ }^{8}$ a correlate of reduced crisis-oriented care such as emergency department visits and inpatient hospitalizations. ${ }^{9}$

Despite a decade of success, SCHIP was scheduled to sunset on September 30, 2007. Although President Bush's stated position was to "put poorer children first," ${ }^{10}$ he vetoed 2 versions of the Children's Health Insurance Program Reauthorization Act of 2007 (HR $976^{11}$ and HR 3963'2). Both versions, which received bipartisan support, would have extended health care benefits to 4 million previously uninsured low-income children. The vetoes reflected 4 main areas of ideological difference between the Bush Administration and legislators. ${ }^{3}$ First, opponents maintained that the program would be too costly. Under the proposed legislation, income eligibility limits for children living in low-income families would have increased from $200 \%$ to $300 \%$ of the FPL ( $\$ 51,510$ annual income for a family of 3 in 2007), which would account for $17.2 \%$ of the population under the age of 18 years. ${ }^{13}$ Opponents asserted that this income level was too high, edging into the middle-class range. Second, some feared that raising the threshold income level would lead some families to drop their private insurance and replace it with public insurance, thus "crowding out" private coverage. Third, the expansion of coverage would have been funded by additional tobacco taxes, an option opposed by tobacco companies. Finally, opposition to the program was generated by the eligibility of US adults with and without children and the enrollment of illegal immigrants.

However, according to a recent assessment by Sarah Rosenbaum in The New England Journal of Medicine, ${ }^{14}$ the main consideration in the presidential vetoes was not enrollment expansion or crowd-out but political ideology. The President, she noted, has argued for a limited government role in overseeing the private health care market: 
The SCHIP battle became a proxy war over the duties that government should assume in national health reform. As SCHIP's reach has grown, the program has wandered into an enormous ideological divide over whether government should be permitted to act as a group sponsor and monitor of plan accountability. The use of government as purchaser and market overseer itself represents a crucial policy and political compromise between advocates of pure public insurance models and proponents of full market deregulation.

While moving incrementally toward realization of its original legislative intent, SCHIP has become a symbol for the current ideological divide over the role of government versus private markets in health care initiatives. As was the case in the Medicare Modernization Act of 2003, the President has an ideological commitment to a limited government role in health care initiatives and a preference for market-based solutions. While this is generally consistent with the Republican Party's position, the vetoed extensions of SCHIP had support from some congressional Republicans.

Under a subsequent compromise, SCHIP received a 1-year extension. Congress and the President devised a mutually acceptable bill—the Medicare, Medicaid, and SCHIP Extension Act of 2007 (S 2499)—that was signed by the President on December 29, 2007.15 It reauthorizes SCHIP until March 31, 2009, maintaining current funding and coverage levels for 1 year. This brief extension of SCHIP has 2 perverse outcomes: it provides no funding for expanded enrollment of uninsured children living in low-income families, and it sets a precedent for a reduced federal role in addressing health care access for children.

State flexibility in administering SCHIP was further limited by a 2007 federal directive. According to a guidance from the Centers for Medicare and Medicaid Services (CMS), ${ }^{16}$ states that seek to insure low-income children living at $250 \%$ of the FPL ( $\$ 42,925$ for a family of 3 in $2007^{17}$ ) must document that $95 \%$ of eligible children living at $<200 \%$ of the FPL ( $\$ 34,340$ annual income for a family of 3 in 200717) are enrolled in SCHIP; that private insurance coverage has not shrunk more than $2 \%$ in the past 5 years; that the state will impose a 1 -year waiting period before children whose parents have cancelled private insurance can be considered eligible for SCHIP; and that they are implementing strategies to prevent crowd-out. Although these requirements do not apply to current enrollees, states have 1 year to amend their state SCHIP plans or face corrective action. This guidance is meaningful because it restricts states' flexibility in tailoring programs to local needs and conditions. It also limits expansion of eligibility at a time when the number of uninsured low-income children is rising, medical costs are escalating, and health premiums are increasing. The most likely impact of the CMS guidance and the terms of the SCHIP extension is that the number of low-income children without health care coverage will increase. However, if the CMS requirements are satisfied, states may extend SCHIP coverage to children whose families earn up to $250 \%$ of the FPL. ${ }^{16}$ If the requirements are not met, then federal funding can be denied. ${ }^{14}$ Given the large federal match (an average of $70 \%$ ), a sluggish economy, and mounting state debts, states cannot afford to fail to meet these requirements. Consequently, it is unlikely that states will move forward with expanding coverage to low-income children living beyond $250 \%$ of the FPL.

With 47 million people, including 9 million children, uninsured across the United States, ${ }^{18}$ health care reform will remain at the forefront of the 2008 presidential campaign. Democratic and Republican candidates vying for the White House have made a commitment to reforming the US health care system and protecting the uninsured. Will their subsequent decisions reflect political symbolism or fiscal realities?

Democratic presidential candidate Hillary Clinton endorses high-quality, affordable health care. Specifically, her health plan would provide "tax credits for working families to help them cover their costs" and "ensure that working families never have to pay more than a limited percentage of their income for health care." 19 Health costs would be reduced by focusing on disease prevention, modernization of the health system, and increasing the use of generic drugs. ${ }^{20}$ Senator Clinton supports strengthening SCHIP by fixing "the holes in the safety net to ensure that the most vulnerable populations receive affordable, quality care." 21

Republican presidential candidate John McCain supports the principles of access to health care for all Americans, reducing the cost of health care, and promoting competition. Specifically, he has stated that "insurance reforms should increase the variety and affordability of insurance coverage available to American families by fostering competition and innovation." 22 If Senator McCain follows the Republican Party platform, he can be expected to propose a standard tax deduction for health insurance that would lower taxes and make health care more af- 
fordable. ${ }^{23}$ Such an approach would be most relevant to those who have the financial resources to purchase private health insurance and who also lack disqualifying preexisting medical conditions. Concerning pharmaceuticals, Senator McCain is on record as supporting increased use of generic drugs and drug reimportation as mechanisms for stimulating competition. ${ }^{23}$

Democratic presidential candidate Barack Obama advocates affordable health insurance coverage, including mandatory coverage for children, and expansion of SCHIP and Medicaid. ${ }^{24}$ Specifically, Senator Obama supports increasing competition in the health industry and pharmaceutical markets, lowering the cost of prescription drugs by increasing the use of generics, permitting Americans to purchase drugs from other developed countries, and reversing the prohibition on direct federal government price negotiation with pharmaceutical companies that was established under the Medicare Modernization Act of 2003.

The SCHIP extension will end during the next President's first term. The presidential primaries have focused on within-party differences in an attempt to clearly demarcate the positions that distinguish the candidates. Such contrasts are likely to be forgotten once the candidates are selected and between-party differences are emphasized. Congress has demonstrated bipartisan willingness to address health care access for uninsured children, and the current political discourse does not suggest that it will reverse its position when SCHIP is reconsidered. Consequently, the continued existence of SCHIP and its specific features are likely to be shaped by the next President.

Lorenda A. Naylor, PhD, MPH, MPA Assistant Professor, School of Public Affairs University of Baltimore Baltimore, Maryland

Alan Lyles, ScD, MPH, RPh Section Co-Editor

\section{REFERENCES}

1. Balanced Budget Act of 1997. Public Law 105-33. http://www.cms.hhs.gov/NationalSCHIPPolicy [then select SCHIP Legislation]. Accessed March 2, 2008.

2. Congress of the United States, Congressional Budget Office. A CBO paper: The State Children's Health Insurance Program. May 2007. http://www.cbo.gov/ftpdocs/80xx/doc8092/05-10-SCHIP.pdf. Accessed March 2, 2008.

3. The Kaiser Commission on Medicaid and the Uninsured. State Children's Health Insurance Program (SCHIP): Reauthorization history [The Henry J. Kaiser Family Foundation Web site]. January 2008. http://www.kff.org/medicaid/upload/7743.pdf. Accessed February 29, 2008.

4. Policy position. HHS-09. The State Children's Health Insurance Program (S-CHIP) [National Governors' Association Web site]. http://www.nga.org/portal/site/nga/menuitem.8358ec82f5b198d18a278110501010a0/?vgnextoid=20da9e2f1b091010 VgnVCM1000001a01010aRCRD. Accessed February 29, 2008.

5. US Dept of Health \& Human Services. The 2007 HHS poverty guidelines: One version of the [U.S.] federal poverty measure. http://aspe.hhs.gov/poverty/07poverty.shtml. Accessed March 2, 2008.

6. Centers for Medicare and Medicaid Services. SCHIP ever enrolled in year. http://www.cms.hhs.gov/NationalSCHIPPolicy/ downloads/SCHIPEverEnrolledYearGraph.pdf. Accessed March 2, 2008.

7. US Dept of Health \& Human Services, Centers for Disease Control and Prevention, National Center for Health Statistics. Table 81. No health care visits for an office or clinic within the past 12 months among children under 18 years of age, by selected characteristics: United States, average annual 1997-1998, 2001-2002, and 2004-2005. In: Health, United States, 2007: With Chartbook on Trends in the Health of Americans. November 2007. DHHS Publ no 2007-1232. http://www.cdc.gov/nchs/ data/hus/hus07.pdf\#executivesummary. Accessed March 3, 2008.

8. March 27, 2007. Testimony by NGA Executive Director Ray Scheppach before the House Energy and Commerce Subcommittee on Health on "insuring bright futures: Improving access to dental care and providing a healthy start for children [National Governors' Association Web site].” March 27, 2007. http://www.nga.org/portal/site/nga/menuitem.0f8c660ba7cf98d18a27 8110501010a0/?vgnextoid=8a9dc486eaf81110VgnVCM1000001a01010aRCRD. Accessed February 29, 2008. 
9. US General Accounting Office. Report to Congressional Requesters. Medicaid and SCHIP. States use varying approaches to monitor children's access to health care. January 2003. GAO-03-222. http://www.gao.gov/new.items/d03222.pdf. Accessed March 3, 2008.

10. Bush GW. Message to the House of Representatives. October 3, 2007. http://www.whitehouse.gov/news/releases/2007/10/ 20071003-2.html. Accessed February 29, 2008.

11. H.R. 976. Children's Health Insurance Program Reauthorization Act of 2007 [The Library of Congress Thomas Web site]. http://thomas.loc.gov/. Accessed March 3, 2008.

12. H.R. 3963. Children's Health Insurance Program Reauthorization Act of 2007 [The Library of Congress Thomas Web site]. http://thomas.loc.gov/. Accessed March 3, 2008.

13. Prante G. Fiscal facts. What is 300 percent of the poverty level [Tax Foundation Web site]? http://www.taxfoundation.org/ news/show/22471.html. Accessed March 3, 2008.

14. Rosenbaum S. The proxy war-SCHIP and the government's role in health care reform. N EnglJ Med. 2008;358:869-872.

15. A bill to amend titles XVIII, XIX, and XXI of the Social Security Act to extend provisions under the Medicare, Medicaid, and SCHIP programs, and for other purposes. Bill \#S.2499 [Congress.org Web site]. http://www.congress.org/congressorg/issues/ bills/?billnum=S.2499\&congress=110\&size=full. Accessed March 3, 2008.

16. Smith DG. Dear State Health Official letter. SHO \#07-001. August 17, 2007. http://www.cms.hhs.gov/smdl/downloads/ SHO081707.pdf. Accessed March 3, 2008.

17. Centers for Medicare and Medicaid Services. 2007 Poverty level guidelines. http://www.cms.hhs.gov/MedicaidEligibility/ downloads/POV07ALL.pdf. Accessed March 2, 2008.

18. Census Bureau revises 2004 and 2005 health insurance coverage estimates [press release]. March 23, 2007. http://www.census. gov/Press-Release/www/releases/archives/health_care_insurance/009789.html. Accessed March 2, 2008.

19. Providing affordable and accessible health care [Hillary for President Web site]. http://www.hillaryclinton.com/issues/health care/. Accessed March 3, 2008.

20. Supporting parents and caring for children [Hillary for President Web site]. http://www.hillaryclinton.com/issues/family/. Accessed March 3, 2008.

21. American health choices plan: Quality, affordable health care for every American [Hillary for President Web site]. http://www. hillaryclinton.com/feature/healthcareplan/americanhealthchoicesplan.pdf. Accessed March 3, 2008.

22. Straight talk on health system reform [John McCain 2008 Web site]. http://www.johnmccain.com/Informing/Issues/19ba2f1c c03f-4ac2-8cd5-5cf2edb527cf.htm. Accessed March 3, 2008.

23. Health care [gop.com Web site]. http://healthcare.gop.com/GroupPage.aspx. Accessed March 3, 2008.

24. Health care: Plan for a healthy America [Obama '08 Web site]. http://www.barackobama.com/issues/healthcare/\#coveragefor-all. Accessed March 3, 2008. 